\title{
Molecular complexes of the triterpene glycosides with $L$-tyrosine and their biological activity
}

\author{
L. A. Yakovishin, A. V. Lekar ${ }^{1}$, E. V. Vetrova ${ }^{2}$, N. I. Borisenko ${ }^{1}$, \\ S. N. Borisenko², V. I. Grishkovets ${ }^{3}$
}

Sevastopol National Technical University

33, Universytetska Str., Sevastopol, Ukraine, 99053

${ }^{1}$ Ecological and Analytical Center, Southern Federal University

7, R. Zorge Str., Rostov-on-Don, Russian Federation, 344090

The Resesarch Institute of Physical and Organic Chemistry, Southern Federal University

194/2, pr. Stachki, Rostov-on-Don, Russian Federation, 344090

${ }^{3}$ Taurida National V. I. Vernadsky University

4, pr. Vernadsky, 4, Simferopol, Ukraine, 95007

chemsevntu@rambler.ru

\begin{abstract}
Aim. To investigate the complexation of L-tyrosine (Tyr) with hedera-genin 3-O- $\alpha$-L-rhamnopyranosyl- $(1 \rightarrow$ 2)-O- $\alpha$ - $L$ - arabinopyranoside ( $\alpha$-hederin) and its $28-O-\alpha-L$-rhamnopyranosyl- $(1 \rightarrow 4)-O$ - $\beta$ - $D$-glucopyranosyl-(1 $\rightarrow 6)-O-\beta-D$-glucopyranosyl ester (hederasaponin $C)$; to study the effect of glycosides, Tyr, and their mixtures on Avena sativa L. seed germination. Methods. Electrospray ionization mass spectrometry. Results. Mass spectra of mixes of glycosides with Tyr have been received and interpreted. The comparative analysis of biological activity of indivi- dual glycosides and their complexes with Tyr and others aromatic amino acids has been performed. Conclusions. For the first time a composition of the complexes is established by mass spectrometry. The complex of $\alpha$ - hederin with Tyr has appeared most toxic.
\end{abstract}

Keywords: $\alpha$-hederin, hederasaponin C, L-tyrosine, complexa- tion, mass spectrometry, Avena sativa L.

Introduction. At present more and more attention is paid to the methods of obtaining molecular complexes of different biologically active substances with plant saponins and the elaboration of novel medical preparations on their basis [1-9]. In particular, the complexes with aromatic amino acids were synthesized. They include the most investigated complexation of amino acids with steroid saponins [10-13] which was confirmed by the time-of-flight plasma-desorption mass spectrometry with ${ }^{252} \mathrm{Cf}$ fission-fragment ionization as well as by NMR and UV-spectroscopy. There is a veterinary preparation "Clatiram" which is the complex of cloprostenol prostaglandin, $L$-tyrosine (Tyr) and glycyrrhizic acid, the main triterpene gly-

(C) Institute of Molecular Biology and Genetics, NAS of Ukraine, 2012 coside of Glycyrrhiza [14]. It is used for the purposes of regulating the reproductive function of animals.

There has been started the study on the complexation of triterpene glycosides of $\alpha$-hederin (hederagenin3-O- $\alpha$-L-rham-nopyranosyl- $(1 \rightarrow 2)-\mathrm{O}-\alpha$-L-arabi nopyranoside, glycoside 1 , Fig. 1) and its $28-\mathrm{O}-\alpha-$ L-rhamnopyranosyl-( $1 \rightarrow 4)-\mathrm{O}-\beta$-D-glycopyranol-( $1 \rightarrow$ 6)-O- $\beta$-D-glycopyranosyl ester (hederasaponin $\mathrm{C}$, glycoside 2, Fig. 1). The complexes of glycosides $\mathbf{1}$ and $\mathbf{2}$ with amino acids, cholesterol, sildenafil, laevomycetin (chloramphenicol), caffeine and streptocid were obtained [15]. Glycosides $\mathbf{1}$ and $\mathbf{2}$ were discovered in representatives of the majority of Hedera L. species where they are prevailing saponins [16-21]. Glycosides $\mathbf{1}$ and 2 are a part of anticough drugs, containing Hedera helix L. leaves extract $[16,22]$. 


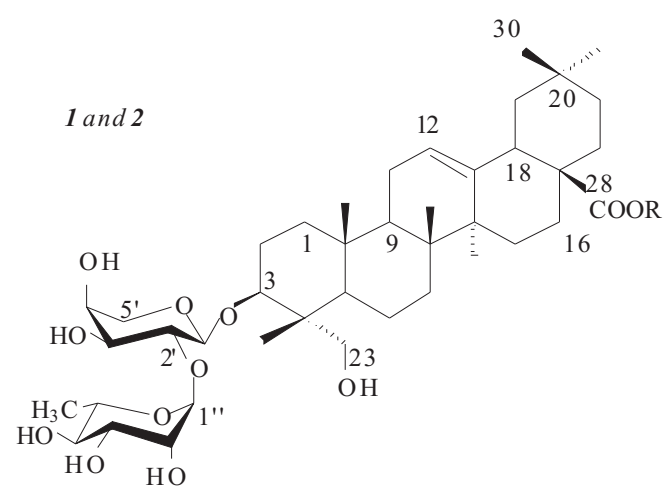

The electrospray ionization mass spectrometry was used to study the complexation of glycosides $\mathbf{1}$ and $\mathbf{2}$ with $L$-phenylalanine (Phe) [23], $L$-tryptophan (Trp) [15] and L-histidine (His) [24]. Besides, we have established the effect of these complexes on the germinating ability of seeds and further development of Avena sativa L. sprouts [24-26]. However, Tyr complexes were previously analyzed only by UV-spectrometry [27]. Therefore, the current article presents the results of mass-spectrometry analysis of the interaction of glycosides $\mathbf{1}$ and $\mathbf{2}$ with Tyr to systematize the data on the complexation of triterpene saponins with aromatic amino acids. Also we reviewed the effect of complexes on the germinating ability of seeds.

Materials and Methods. Glycosides $\mathbf{1}$ and $\mathbf{2}$ were extracted from the leaves of Hedera taurica Carr. and Hedera canariensis Willd. The composition of glycosides was confirmed by the methods, presented in [17, 18].

The complexes of glycoside 1 were obtained by mixing the solutions containing $1 \mathrm{mmol}$ glycoside and $1 \mathrm{mmol}$ Tyr while for preparing the complexes of glycoside $\mathbf{2}$ the solutions were mixed in a molar ratio of $1: 2$. As a solvent, the mixture of $70 \%$ aqueous solution of $\mathrm{C}_{2} \mathrm{H}_{5} \mathrm{OH}$ and $\mathrm{CHCl}_{3}$ in a volume ratio of $3: 1$ was used. The solutions were kept at $50^{\circ} \mathrm{C}$ for $1.5 \mathrm{~h}$ at constant stirring. The organic solvents were removed in the vacuum; the obtained mixtures were used for mass-spectra filming.

The measurements were conducted using Bruker Daltonic micrOTOF-Q mass-spectrometer with directinlet probe, electrospray ionization, detection of negative and positive ions in the range of 50-3,000 Da. The voltage at the restrictor tube was $\pm 4200 \mathrm{~V}$, the gas drier parameters (nitrogen ACS, $51 / \mathrm{min}, 180{ }^{\circ} \mathrm{C}$ ) and the
Tyr<smiles>NC(Cc1ccc(O)cc1)C(=O)O</smiles>

Fig. 1 The composition of molecular complex components (glycoside 1: R $=\mathrm{H}$; glycoside $2: \mathrm{R}=\leftarrow \beta \mathrm{Glc}_{\mathrm{p}}-(6 \leftarrow 1)-$ $\beta \mathrm{Glc}_{\mathrm{p}}-(4 \leftarrow 1)-\alpha \mathrm{Rha}_{\mathrm{p}}$

energy of ions at the quadrupole $(5.0 \mathrm{eV})$ were optimized to detect the peaks of pseudomolecular and associative ions. The solutions of substances in acetonitrile (Merck, HPLC/MS) in the concentration up to $1 \mathrm{mg} / \mathrm{ml}$ were used for direct inlet, the inlet rate did not exceed $0.05 \mu \mathrm{l} / \mathrm{s}$. The $\mathrm{m} / z$ ratios and the values of relative intensities of the ion peaks $\left(I_{\text {rel }}, \%\right)$ are presented in Table 1.

The germinating ability of $A$. sativa $\mathrm{L}$. seeds (Poaceae (Gramineae) family) was checked in the laboratory conditions at room temperature $\left(23-25^{\circ} \mathrm{C}\right)$ as described in [24]. The results are presented in Table 2.

Results and Discussion. Mass-spectrometry of mixtures of glycosides 1 and 2 with Tyr. The ion peak $\left[\mathrm{M}^{1}+\mathrm{M}^{\mathrm{Tyr}}-\mathrm{H}\right]^{-}$with $m / z 930.5$, corresponding to the formation of the complex of 1:1 composition, was registered in the mode of negative ions for the mixture of glycoside 1 and Tyr. The peaks of ions of three molecular complexes $\left[\mathrm{M}^{1}+\mathrm{M}^{\mathrm{Tyr}}+\mathrm{H}\right]^{+},\left[2 \mathrm{M}^{1}+\mathrm{M}^{\mathrm{Tyr}}+\right.$ $\mathrm{H}]^{+}$and $\left[3 \mathrm{M}^{1}+\mathrm{M}^{\mathrm{Tyr}}+\mathrm{H}\right]^{+}$were observed in the mass-spectrum of positive ions besides the peaks of protonated Tyr and glycoside 1, their self-associates as well as the adducts with $\mathrm{Na}^{+}$and $\mathrm{K}^{+}$ions (Fig. 2, Table 1). The ratio of peak intensities of these ions is 632:28:1. Therefore, the complex with Tyr, the composition of which is $1: 1$, is more typical for glycoside 1 . The formation of the analogous complex out of Tyr and glycoside 1 has recently been proven by the isomolar series method [27].

The complexes of glycoside 2 with Tyr are not registered in the negative ion mode. There are only the ions of deprotonated glycoside $\mathbf{2}$ and Tyr. However, the peaks $\left[\mathrm{M}^{2}+\mathrm{M}^{\mathrm{Tyr}}+\mathrm{H}\right]^{+}$and $\left[3 \mathrm{M}^{2}+2 \mathrm{M}^{\mathrm{Tyr}}+\mathrm{H}\right]^{+}$, corresponding to the complexes of $1: 1$ and $3: 2$ ratios, respectively, were registered in the positive ion mode 
Table 1

Mass-spectra of the mixtures of Tyr with glycosides 1 and $\mathbf{2}$

\begin{tabular}{|c|c|c|c|}
\hline Ion & $m / z\left(\mathrm{I}_{\mathrm{rel}}, \%\right)$ & Ion & $m / z\left(\mathrm{I}_{\mathrm{rel}}, \%\right)$ \\
\hline \multicolumn{2}{|c|}{ Mixture of Tyr and glycoside 1} & \multicolumn{2}{|c|}{ Mixture of Tyr and glycoside 1} \\
\hline$\left[\mathrm{M}^{\mathrm{Tyr}}-\mathrm{H}\right]^{-}$ & $180,1(26,68)$ & {$\left[2 \mathrm{M}^{1}+\mathrm{M}^{\mathrm{Tyr}}+\mathrm{H}\right]^{+}$} & $1682,7(0,83)$ \\
\hline$\left[2 \mathrm{M}^{\mathrm{Tyr}}-\mathrm{H}\right]^{-}$ & $361,1(1,94)$ & {$\left[3 \mathrm{M}^{1}+\mathrm{M}^{\mathrm{Tyr}}+\mathrm{H}\right]^{+}$} & $2433,2(0,03)$ \\
\hline$\left[\mathrm{M}^{1}-\mathrm{H}\right]^{-}$ & $749,4(70)$ & \multicolumn{2}{|c|}{ Mixture of Tyr and glycoside $\mathbf{2}$} \\
\hline $\begin{array}{c}{\left[\mathrm{M}^{1} \ldots\left(\mathrm{M}^{1}-\mathrm{H}\right) \ldots \mathrm{M}^{1} \ldots\left(\mathrm{M}^{1}-\mathrm{H}\right)\right]^{2-} \text { or }} \\
{\left[\mathrm{M}^{1} \ldots\left(\mathrm{M}^{1}-2 \mathrm{H}\right) \ldots 2 \mathrm{M}^{1}\right]^{2-}}\end{array}$ & $1499,8(3,02)$ & {$\left[\mathrm{M}^{\mathrm{Tyr}}-\mathrm{H}\right]^{-}$} & $180,2(10,42)$ \\
\hline $\begin{array}{c}{\left[\left(\mathrm{M}^{1}-\mathrm{H}\right) \ldots \mathrm{M}^{1} \ldots\left(\mathrm{M}^{1}-\mathrm{H}\right)\right]^{2-} \text { or }} \\
\quad\left[\mathrm{M}^{1} \ldots\left(\mathrm{M}^{1}-2 \mathrm{H}\right) \ldots \mathrm{M}^{1}\right]^{2-}\end{array}$ & $1124,6(3,71)$ & {$\left[\mathrm{M}^{2}-\mathrm{H}\right]^{-}$} & $1220,0(16,96)$ \\
\hline$\left[\mathrm{M}^{1} \ldots\left(\mathrm{M}^{1}-\mathrm{H}\right) \ldots \mathrm{M}^{1} \ldots\left(\mathrm{M}^{1}-\mathrm{H}\right) \ldots \mathrm{M}^{1}\right]^{2-}$ & $1875,5(0,17)$ & {$\left[\mathrm{M}^{2}-2 \mathrm{H}\right]^{2-}$} & $609,5(23,55)$ \\
\hline$\left[\mathrm{M}^{1}+\mathrm{M}^{\mathrm{Tyr}}-\mathrm{H}\right]^{-}$ & $930,5(9,42)$ & {$\left[\mathrm{M}^{\mathrm{Tyr}}+\mathrm{H}\right]^{+}$} & $182,0(100)$ \\
\hline$\left[\mathrm{M}^{\mathrm{Tyr}}+\mathrm{H}\right]^{+}$ & $182,0(100)$ & {$\left[\mathrm{M}^{\mathrm{Tyr}}+\mathrm{Na}\right]^{+}$} & $205,0(2,06)$ \\
\hline$\left[\mathrm{M}^{\mathrm{Tyr}}+\mathrm{Na}\right]^{+}$ & $205,0(0,85)$ & {$\left[2 \mathrm{M}^{\mathrm{Tyr}}+\mathrm{H}\right]^{+}$} & $363,0(1,23)$ \\
\hline$\left[\mathrm{M}^{\mathrm{Tyr}}+\mathrm{K}\right]^{+}$ & $221,0(2,51)$ & {$\left[2 \mathrm{M}^{\mathrm{Tyr}}+\mathrm{Na}\right]^{+}$} & $385,1(0,32)$ \\
\hline$\left[2 \mathrm{M}^{\mathrm{Tyr}}+\mathrm{H}\right]^{+}$ & $363,0(12,23)$ & {$\left[\mathrm{M}^{2}+\mathrm{M}^{\mathrm{Tyr}}+\mathrm{H}\right]^{+}$} & $1402,5(1,91)$ \\
\hline$\left[2 \mathrm{M}^{\mathrm{Tyr}}+\mathrm{Na}\right]^{+}$ & $385,0(4,97)$ & {$\left[\mathrm{M}^{\mathrm{Tyr}}+\mathrm{K}\right]^{+}$} & $220,0(1,53)$ \\
\hline$\left[\mathrm{M}^{1}+\mathrm{H}\right]^{+}$ & $751,3(38,05)$ & {$\left[2 \mathrm{M}^{\mathrm{Tyr}}+\mathrm{K}\right]^{+}$} & $401,1(0,57)$ \\
\hline$\left[\mathrm{M}^{1}+\mathrm{Na}\right]^{+}$ & $773,4(4,78)$ & {$\left[3 \mathrm{M}^{\mathrm{Tyr}}+\mathrm{Na}\right]^{+}$} & $566,3(0,14)$ \\
\hline$\left[\mathrm{M}^{1}+\mathrm{K}\right]^{+}$ & $789,4(0,74)$ & {$\left[3 \mathrm{M}^{\mathrm{Tyr}}+\mathrm{K}\right]^{+}$} & $582,3(0,20)$ \\
\hline$\left[4 \mathrm{M}^{1}+2 \mathrm{Na}\right]^{2+}$ & $1523,6(0,25)$ & {$\left[4 \mathrm{M}^{\mathrm{Tyr}}+\mathrm{H}\right]^{+}$} & $725,3(0,14)$ \\
\hline$\left[2 \mathrm{M}^{1}+\mathrm{H}\right]^{+}$ & $1501,7(2,23)$ & {$\left[4 \mathrm{M}^{\mathrm{Tyr}}+\mathrm{K}\right]^{+}$} & $764,4(1,02)$ \\
\hline$\left[3 \mathrm{M}^{1}+\mathrm{H}\right]^{+}$ & $2252,1(0,20)$ & {$\left[3 \mathrm{M}^{2}+2 \mathrm{M}^{\mathrm{Tyr}}+\mathrm{H}\right]^{+}$} & $2013,2(0,08)$ \\
\hline$\left[\mathrm{M}^{1}+\mathrm{M}^{\mathrm{Tyr}}+\mathrm{H}\right]^{+}$ & $932,3(18,96)$ & - & - \\
\hline
\end{tabular}

(Fig. 3, Table 1). The peak intensities of these ions are in the ratio of 24:1 which indicated the prevalence of the complex of equimolar composition.

Previously, using the electrospray ionization mass-spectrometry we showed that for the glycosides $\mathbf{1}$ and 2 and amino acids (Trp, Phe and His) the complexes of 1:1 composition are the most typical $[15,23$, 24]. The amino acid Tyr differs from Phe structurally only by the presence of a hydroxyl group. It should be noted that in the same experimental conditions the peak intensity $\left[\mathrm{M}^{1}+\mathrm{M}^{\mathrm{Tyr}}+\mathrm{H}\right]^{+}$is twice as high as $\left[\mathrm{M}^{1}+\mathrm{M}^{\mathrm{Phe}}\right.$ $+\mathrm{H}]^{+}$. Phe forms with glycoside 1 more varied complexes than with glycoside $\mathbf{2}$. The same regularity was observed for Tyr.
Biological activity. The toxic effect of triterpene glycosides is known to be the inhibition of the plant development. As a rule, this activity is inherent in monodesmosidic glycosides [28]. The effect of glycosides, Tyr and their complexes on the germinating ability and development of $A$. sativa $\mathrm{L}$. sprouts was observed for 24-72 $\mathrm{h}$ (Table 2).

After $72 \mathrm{~h}$ it was determined that only the seeds treated with Tyr solution preserved $100 \%$ germinating ability while for the seeds, preliminarily kept in the mixtures of glycosides $\mathbf{1}$ and $\mathbf{2}$ with Tyr, it was $\mathbf{4 4}$ and $80 \%$, respectively which is 2.09 and 1.15 times less than for the seeds, kept in water. In addition, the mixture of glycoside $\mathbf{1}$ with Tyr inhibits the germinating 
Table 2

The germination of Avena sativa seeds in laboratory conditions (concentrations of individual substances and substances in mixtures $10^{-4} \mathrm{M}$ )

\begin{tabular}{|c|c|c|c|c|c|c|}
\hline \multirow{2}{*}{ Parameter } & \multicolumn{6}{|c|}{ Compound } \\
\hline & $\mathrm{H}_{2} \mathrm{O}$ (control) & 1 & 2 & Tyr & 1-Tyr mixture & 2-Tyr mixture \\
\hline \multicolumn{7}{|l|}{$24 \mathrm{~h}$ later } \\
\hline Germination, $\%$ & 0 & 0 & 0 & 0 & 0 & 0 \\
\hline Stem length, mm & - & - & - & - & - & - \\
\hline Amount with the root, $\%$ & 92 & 92 & 84 & 96 & 100 & 96 \\
\hline Root length, mm & $2,6 \pm 0,6$ & $3,0 \pm 1,4$ & $3,3 \pm 0,7$ & $2,8 \pm 0,6$ & $1,6 \pm 1,1$ & $2,5 \pm 1,1$ \\
\hline \multicolumn{7}{|l|}{$48 \mathrm{~h}$ later } \\
\hline Germination, $\%$ & 56 & 28 & 40 & 64 & 8 & 56 \\
\hline Stem length, mm & $1,0 \pm 0,6$ & $0,6 \pm 0,9$ & $0,5 \pm 1,3$ & $1,9 \pm 0,6$ & $1,5 \pm 0,9$ & $1,1 \pm 0,6$ \\
\hline Amount with the root, $\%$ & 94 & 100 & 88 & 96 & 100 & 96 \\
\hline Длина корня, мм & $4,6 \pm 0,5$ & $3,3 \pm 0,8$ & $3,5 \pm 1,2$ & $5,9 \pm 1,1$ & $3,5 \pm 0,6$ & $4,9 \pm 0,6$ \\
\hline \multicolumn{7}{|l|}{$72 \mathrm{~h}$ later } \\
\hline Germination, \% & 92 & 60 & 86 & 100 & 44 & 80 \\
\hline Root length, mm & $4,2 \pm 0,6$ & $3,5 \pm 1,3$ & $3,7 \pm 0,6$ & $4,6 \pm 0,8$ & $2,4 \pm 0,7$ & $4,6 \pm 0,7$ \\
\hline Amount with the root, $\%$ & 96 & 100 & 96 & 100 & 100 & 100 \\
\hline Root length, mm & $7,1 \pm 0,6$ & $5,5 \pm 1,1$ & $6,4 \pm 0,8$ & $7,6 \pm 0,9$ & $4,5 \pm 0,8$ & $3,3 \pm 0,6$ \\
\hline
\end{tabular}

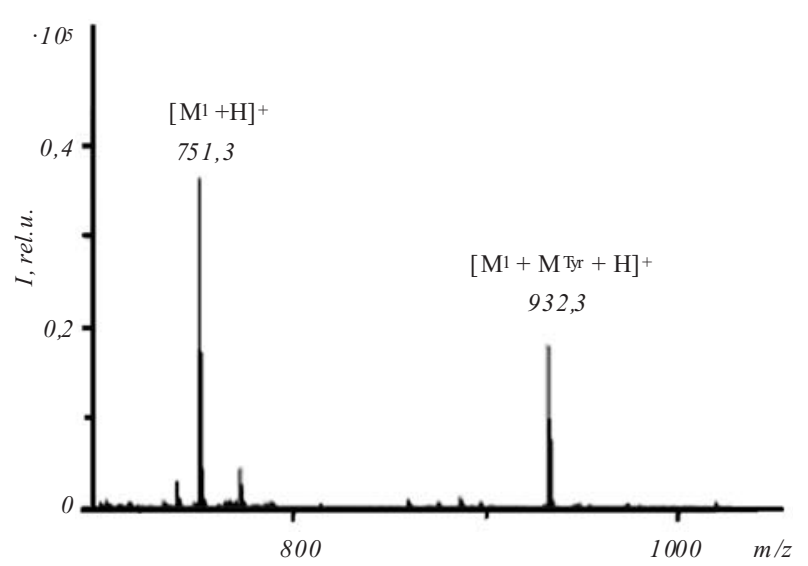

Fig. 2 The fragment of mass-spectra of positive ions of the mixture of glycoside 1 and Tyr

ability stronger than the solution of individual glycoside 1 . The seeds, treated with the complex of glycoside $\mathbf{2}$ with Tyr and the solution of individual glycoside $\mathbf{2}$, have similar germinating ability. Therefore, the mixture of glycoside 1 with Tyr reduces the germinating ability of the seeds to the greatest extent.
The share of sprouts with roots when using all the substances and in the control group is 96-100\%. However, the length of the sprout root after the treatment with the complex of glycoside 2 with Tyr was approximately half the length of those treated with glycoside $\mathbf{2}$ and Tyr separately, as well as compared to the control. The complex of glycoside $\mathbf{1}$ and Tyr inhibits the root growth to a lesser degree.

The sprout length after the seed treatment with 1-Tyr complex is approximately twice less than that of the Tyr-treated seeds and the control group. The effect of 2-Tyr complex leads to the occurrence of the sprouts with approximately the same length as in control and Tyr-treated plants.

Previously we established that the complexes of glycosides $\mathbf{1}$ and $\mathbf{2}$ with Phe [25] and His [24] are less toxic than individual glycosides. Vice versa, the complexes with Trp proved to be more toxic [26]. The complexes of glycoside $\mathbf{1}$ with Tyr and Trp have equal inhibiting effect on the germinating ability $72 \mathrm{~h}$ after the seed treatment. The germinating ability of the seeds, 


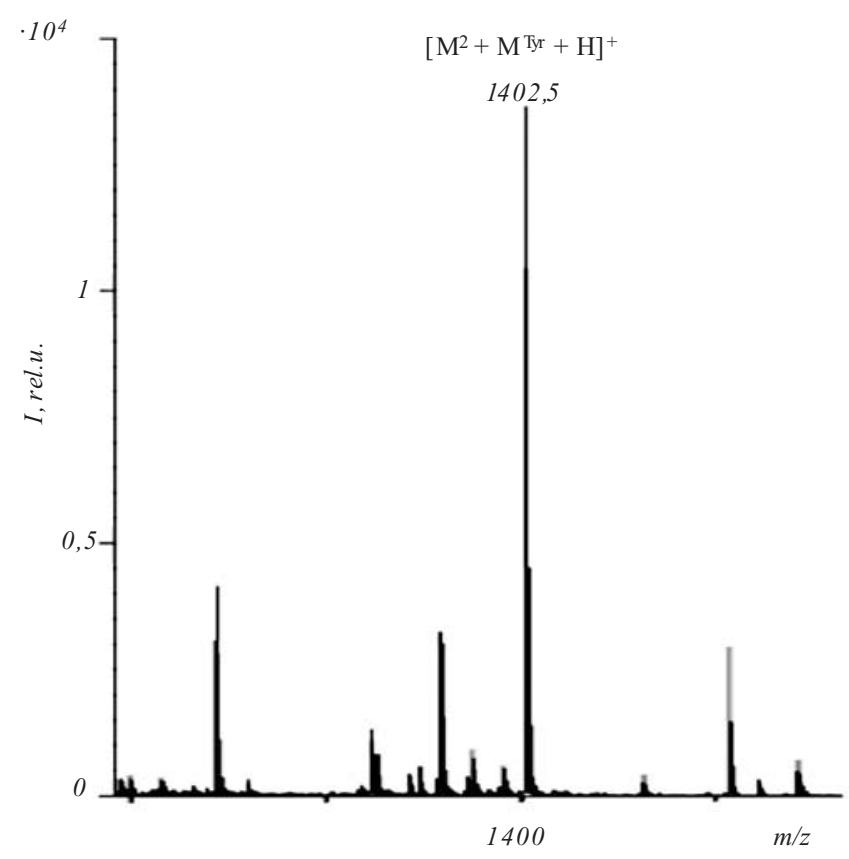

Fig. 3 The fragment of mass-spectra of positive ions of the mixture of glycoside 2 and Tyr

kept in their solutions, is only $44 \%$ which is approximately twice less compared to the control group. These complexes appeared to be the most phytotoxic compared to glycosides $\mathbf{1}$ and $\mathbf{2}$ as well as to their complexes with all aromatic amino acids.

The least inhibiting effect on the germinating ability was demonstrated by the solutions, containing the mixtures of glycoside 1 with His and glycoside 2 with Phe, His, Tyr. Their germinating ability is $88 \%$ (complexes 1-His, 2-Phe, 2-His) and $80 \%$ (complex 2-Tyr).

Conclusions. Therefore, for Tyr and glycosides 1 and $\mathbf{2}$ the most common are the complexes with molar ratio of $1: 1$. Glycoside 1 forms the complexes with a higher composition variety. The mixture of Tyr with glycoside $\mathbf{1}$ has the highest inhibiting effect on the seed germinating ability and limits the sprout length.

Acknowledgements. The work was performed with the financial support of the grants of RFBR 11-03-12141-ofi-m-2011, the President of the Russian Federation MK-4425.2011 and the grant of the Ministry of Education and Science of the Russian Federation DPNNiT No. 3.5193.2011.
Л. А. Яковичин, А. В. Лекарь ${ }^{1}$, Е. В. Ветрова ${ }^{2}$

Н. И. Борисенко ${ }^{1}$ С. Н. Борисенко, В. И. Грииковеи

Молекулярные комплексы тритерпеновых гликозидов с L-тирозином и их биологическая активность

Севастопольский национальный технический университет

Ул. Университетская, 33, Севастополь, Украина, 99053

1 Эколого-аналитический центр Южного федерального университета

Ул. Р. Зорге, 7, Ростов-на-Дону, Российская Федерация, 344090

${ }^{2}$ НИИ физической и органической химии Южного федерального университета

Пр. Стачки, 194/2, Ростов-на-Дону, Российская Федерация, 344090

${ }^{3}$ Таврический национальный университет им. В. И. Вернадского Пр. Вернадского, 4, Симферополь, Украина, 95007

Резюме

Цель. Исследовать комплексообразование L-тирозина (Tyr) c 3-O- $\alpha$-L-рамнопиранозил- $(1 \rightarrow 2)-O-\alpha-L$ - арабинопиранозидом хедерагенина ( $\alpha$-хедерином) и его 28-O- $\alpha-L-$ рамнопиранозил- $(1 \rightarrow$ 4)-O- $\beta$-D-глюкопиранозил- $(1 \rightarrow 6)-O-\beta-D$-глюкопиранозиловым эфиром (хедерасапонином C). Изучить влияние гликозидов, Tуг и их смесей на всхожесть семян Avena sativa L. Mетоды. Масс-спектрометрия с ионизачией электрораспылением. Результаты. Получены и интерпретированы масс-спектры смесей гликозидов с Туг. Проведен сравнительный анализ биологической активности индивидуальных гликозидов и их комп-лексов с Туг и другими ароматическими аминокислотами. Выводы. Впервые масс-спектрометрически установлен состав комплексов. Наиболее токсичным оказался комплекс $\alpha$-хедерина с Tyr.

Ключевые слова: $\alpha$-хедерин, хедерасапонин $C$, L-тирозин, комплексообразование, масс-спектрометрия, Avena sativa $L$.

Л. О. Яковішин, Г. В. Лекарь, О. В. Ветрова, М. І. Борисенко, С. М. Борисенко, В. I. Гришковець

Молекулярні комплекси тритерпенових глікозидів з $L$-тирозином та їхня біологічна активність

Резюме

Mета. Дослідити комплексоутворення L-тирозину (Tyr) з 3-O- $\alpha$ $L$-рамнопіранозил- $(1 \rightarrow 2)$-O- $\alpha$-L-арабінопіранозидом хедерагені-

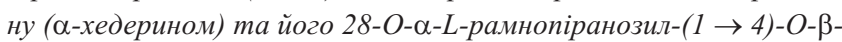
$D$-глюкопіранозил- $(1 \rightarrow 6)-O-\beta-D$-глюкопіранозиловим естером (хедерасапоніном (). Вивчити вплив глікозидів, Tуг та їхніх сумішей на проростання насіння Avena sativa L. Методи. Мас-спектрометрія з іонізацією електророзпиленням. Результати. Отримано та інтерпретовано мас-спектри сумішей глікозидів з Туг. Проведено порівняльний аналіз біологічної активності індивідуальних глікозидів і їхніх комплексів з Туг та іншими ароматичними амінокислотами. Висновки. Вперше методом мас-спектрометрії встановлено склад комплексів. Найтоксичнішим виявився комплекс $\alpha$ хедерину з Туг. 
Ключові слова: $\alpha$-хедерин, хедерасапонін $C, L$-тирозин, комплексоутворення, мас-спектрометрія, Avena sativa $L$

\section{REFERENCES}

1. Tolstikova T. G., Bryzgalov A. O., Sorokina I. V., Ratushnyak A. S., Zapara T. A., Simonova O. G., Tolstikov G. A. To the nature of the effect of glycosidic clathration of pharmacons // Dokl. Biol. Sci.-2007.-416.-P. 336-337.

2. Tolstikova T. G., Tolstikov A. G., Tolstikov G. A. On the way to low-dose drugs // Vestn. Ross. Akad. Nauk.-2007.-77, N 10.P. 867-874.

3. Polyakov N. E., Khan V. K., Taraban M. B., Leshina T. V., Salakhutdinov N. F., Tolstikov G. A. Complexation of lappaconitine with glycyrrhizic acid: stability and reactivity studies // J. Phys. Chem. B.-2005.-109, N 51.-P. 24526-24530.

4. Polyakov N. E., Leshina T. V. Glycyrrhizic acid as a novel drug delivery vector: synergy of drug transport and efficacy // Open Conf. Proc. J.-2011.-2.-P. 64-72.

5. Hu Y. J., Liu Y., Wang J. B., Xiao X. H., Qu S. S. Study of the interaction between monoammonium glycyrrhizinate and bovine serum albumin // J. Pharm. Biomed. Anal.-2004.-36, N 4.P. 915-919.

6. Lee P. S., Han J. Y., Song T. W., Sung J. H., Kwon O. S., Song S., Chung $Y$. B. Physicochemical characteristics and bioavailability of a novel intestinal metabolite of ginseng saponin (IH901) complexed with beta-cyclodextrin // Int. J. Pharm.-2006.-316, N 1-2.-P. 29-36.

7. Polyakov N. E., Leshina T. V., Salakhutdinov N. F., Konovalova T. A., Kispert L. D. Antioxidant and redox properties of supramolecular complexes of carotenoids with beta-glycyrrhizic acid // Free Radic. Biol. Med.-2006.-40, N 10.-P. 1804-1809.

8. Polyakov N. E., Leshina T. V., Salakhutdinov N. F., Kispert L. D. Host-guest complexes of carotenoids with beta-glycyrrhizic acid // J. Phys. Chem. B.-2006.-110, N 13.-P. 6991-6998.

9. Polyakov N. E., Khan V. K., Taraban M. B., Leshina T. V. Complex of calcium receptor blocker nifedipine with glycyrrhizic acid // J. Phys. Chem. B.-2008.-112, N 14.-P. 4435-4440.

10. Pilipenko V. V., Sukhodub L. F., Aksyonov S. A., Kalinkevich A. N., Kintia P. K. ${ }^{252} \mathrm{Cf}$ plasma desorption mass spectrometric study of interactions of steroid glycosides with amino acids // Rapid Commun. Mass Spectrom.-2000.-14, N 10.-P. 819-823.

11. Pilipenko $V$. V., Sukhodub L. F. Mass spectrometry study of plant steroid glycosides and their interactions with biomolecules // Biopolym. Cell.-2002.-18, N 2.-P. 139-141.

12. Pilipenko V. V., Aksyonov S. A., Kalinkevich A. N., Sukhodub L. $F$. PDMS study of the steroid glycosides interaction with amino acids // Biopolym. Cell.-2000.-16, N 3.-P. 212-219.

13. Gorchakova N. A., Samarskaya T. G., Samarsky V. A., Lezina G. G., Grischenko L. I., Babak V. V. Complexation of cardiac glycosides with amino acids and alkaline earth metals // Eksp. Klin. Farmakol.-1992.-55, N 2.-P. 106-109.

14. Tolstikov G. A., Baltina L. A., Grankina V. P., Kondratenko R. M., Tolstikova T. G. Licorice: biodiversity, chemistry and application in medicine.-Novosibirsk: Geo, 2007.-311 p.
15. Yakovishin L. A., Grishkovets V. I., Schroeder G., Borisenko N. $I$. Molecular complexation of ivy saponins with some drugs and biologically active substances // Functionalized molecules - synthesis, properties and application / Ed. V. I. Rybachenko.-Donetsk: Schidnyj wydawnyczyj dim, 2010.-Chapter 4.- P. 85-103.

16. Hostettmann K., Marston A. Saponins.-Cambridge: Univ. press, 2005.-564 p.

17. Shashkov A. S., Grishkovets V. I., Loloyko A. A., Chirva V. Ya. Triterpene glycosides of Hedera taurica I. Structure of tauroside E from the leaves of Hedera taurica // Khim. Prir. Soedin.1987.-N 3.-P. 363-366.

18. Grishkovets V. I., Sidorov D. Yu., Yakovishin L. A., Arnautov N. N., Shashkov A. S., Chirva V. Ya. Triterpene glycosides of Hedera canariensis I. Structures of glycosides L-A, L-B1, L-B2, L-C, L-D, L-E1, L-G1, L-G2, L-G3, L-G4, L-H1, L-H2, and L-I1 from the leaves of Hedera canariensis // Khim. Prir. Soedin.-1996.-N 3.-P. 377-383.

19. Mshvildadze V., Elias R., Faure R., Rondeau D., Debrauwer L., Dekanosidze G., Kemertelidze E., Balansard G. Triterpenoid saponins from the leaves of Hedera pastuchowii // Chem. Pharm. Bull.-2004.-52, N 12.-P. 1411-1415.

20. Mshvildadze V., Elias R., Faure R., Debrauwer L., Dekanosidze $G$., Kemertelidze E., Balansard $G$. Triterpenoid saponins from berries of Hedera colchica // Chem. Pharm. Bull.-2001.-49, N 6.P. 752-754.

21. Elias R., Diaz-Lanza A. M., Vidal-Ollivier E., Balansard G., Faure R., Babadjamian A. Triterpenoid saponins from the leaves of Hedera helix // J. Nat. Prod.-1991.-54, N 1.-P. 98-103.

22. Buechi S., Bolli R. Efeu - expektorans, mukolytikum und broncholytikum. Botanische und klinische aspekte // Phytotheraphie.-2003.-N 3.-P. 19-22.

23. Lekar A. V., Vetrova E. V., Borisenko N. I., Yakovishin L. A., Grishkovets $V$. I., Borisenko $S$. N. Electrospray ionization mass spectrometry of mixtures of triterpene glycosides with L-phenylalanine // J. Appl. Spectrosc.-2011.-78, N 4.-P. 501-505.

24. Yakovishin L. A., Lekar A. V., Vetrova E. V., Borisenko N. I., Grishkovets $V$. I. Molecular complexes of triterpene glycosides with L-histidine and their biological activity // Biopolym. Cell.2011.-27, N 4.-P. 300-305.

25. Yakovishin L. A., Grishkovets V. I., Sergienko U. I., Korzh E. N. Molecular complexation of triterpene glycosides with L-phenylalanine in water solutions // Sci. Notes of TNU. Ser. Biol. Chem.2010.-23 (62), N 3.-P. 255-261.

26. Yakovishin L. A., Epishina N. V., Belash D. Yu., Yarovoy I. R., Korzh E. N., Grishkovets V. I. Influence of the triterpene glycosides and their molecular complexes with aromatic amino acid on seeds germination in laboratory // VI Int. Sci.-Tech. conf. «Modern trends in theoretical and applied biophysics, physics and chemistry» (26-30 Apr. 2010, Sevastopol).-Sevastopol, 2010.Vol. 1.-P. 350-351.

27. Yakovishin L. A., Grishkovets V. I., Sergienko U. I., Dovgy I. I. Molecular complexation of triterpene glycosides with L-tyrosine in aqueous solutions // Sci. Notes of TNU. Ser. Biol. Chem.2011.-24 (63), N 1.-P. 232-238.

28. Podolak I., Galanty A., Sobolewska D. Saponins as cytotoxic agents: a review // Phytochem. Rev.-2010.-9, N 3.-P. 425-474.

Received 05.11.11 